\title{
INTESTATE SUCCESSION IN SOUTH AFRICA: THE "WESTERNIZATION" OF CUSTOMARY LAW PRACTICES WITHIN A MODERN CONSTITUTIONAL FRAMEWORK
}

\section{INTRODUCTION}

The Republic of South Africa is in a period of reform, attempting to carve a unified and democratic nation from the remnants of centuries of foreign interference and over four decades of apartheid rule that ended in the early 1990s. Indigenous peoples living in the rural areas of South Africa, ostracized and ethnically segregated for generations, have come to rely on a system of customary law in order to regulate the traditional practices and norms that make up their daily lives. The new Constitution of the Republic of South Africa was adopted in 1996. Its goal is to unite the country and all of its diverse peoples into one solid democracy in which equality is guaranteed to every citizen. However, the Constitution also expressly recognizes the benefits inherent in cultural diversity and therefore espouses continued acceptance of the various systems of customary law in place in South Africa.

This Note, using intestate succession procedures in South Africa as an example, proposes that the recognition given to customary law in the new Constitution is scarcely more than lip service and that, if reform movements in other areas of law follow a path similar to the movement for intestate succession, customary law will soon be no more than an insignificant aspect in what will effectively become a completely "Westernized" South Africa.

\section{SOUTH AFRICAN HISTORY}

\section{A. Ethnic Division}

The Republic of South Africa's colorful history goes back many centuries.' As the southernmost country on the African continent, the area has been the goal of successive groups of invaders - from the earliest hominids, through the Stone and Iron ages, to the Khoisan peoples, and finally to the Bantu. ${ }^{2}$ European presence began in 1652 with the Dutch occupation of Table Bay. ${ }^{3}$ The British seized the area, now known as Cape Town in 1795, and

1. See generally ROGER B. BECK, THE History OF SOUTH AFRICA (2000), for a comprehensive historical discussion of Southem Africa from 4 million B.C.E. - 1999, including an extensive timeline of historical events.

2. See South Africa: History, at http://www.comptons.com/encyclopedia/ARTICLES/ 0150/01709056_A. html (last visited Sept. 16, 2000); J.D. OMER-COOPER, HISTORY OF SOUTHERN AFRICA 1-16 (2d ed. 1994) (background information about the Khoisan peoples and Bantu-speaking settlements).

3. See generally South Africa Post-Colonial History: Recent History, at http://www. 
colonized it in 1815, using it as a naval base. Determined to obtain control of the gold mines in Transvaal, the British defeated the Boer armies in the 1899 Boer War' and in May 1910 Britain formally declared the Union of South Africa a dominion under her crown. ${ }^{6}$

In 1948, Jan Smuts, ${ }^{7}$ a South African World War II leader and member of the United Party, lost the general election to the Nationalist Party. ${ }^{8}$ The Nationalist Party (NP) ran on a platform that stressed ethnic separation, including the prevention of mixed marriages, the removal of certain blacks from the common voters' roll, and the segregation of all cities and towns into four distinct ethnic residential areas, or Group Areas. ${ }^{9}$ As leader of the NP, Daniel Malan commenced putting a system of apartheid ${ }^{10}$ into practice, which

newafrica.com/history/ southafrica/post_colonial.htm (last visited Sept. 16, 2000). Now known as Cape Town, the Dutch East Indian fleets used Table Bay as a halfway port. See id. See also T.R.H. DAVENPORT \& M.F. KATZEN, A HISTORY OFSOUTH AFRICA TO 1870 187-232 (Monica Wilson \& Leonard Thompson eds., 1982) (discussing the Dutch settlement of Table Bay and the development of a White Colonial community between 1652-1778); OMER-COOPER, supra note 2, at 17-34 (discussing the establishment and early development of the Cape Colony, including commentary on the introduction of slave labor, Colonial expansion, Khoisan reactions to the European presence and the early development of racial attitudes at the Cape).

4. See South Africa Post-Colonial History: Recent History, supra note 3.

5. The British referred to the 1899 war as the Boer (or Anglo-Boer) War, while the Afrikaners referred to it as the Second War of Freedom (the first being the Anglo-Transvaal War). See BECK, supra note 1, at 92. All South Africans, black and white, were eventually pulled into the conflict, thus making it a civil war as well as an imperialist war. See id. Many historians today, therefore, refer to it as the South African War. See id. For an in-depth analysis of events leading up to the Boer War and the resulting White domination following the War, see T.R.H. DAVENPORT, SOUTH AFRICA: A MODERN HISTORY $97-169$ (1977).

6. See South Africa Post-Colonial History: Recent History, supra note 3.

7. Smuts, a World War I hero, was also an Afrikaner General in the Boer War. See BECK, supra note 1, at 93. He later served as Deputy Prime Minister of South Africa. See id. at 103. He had become a "major figure on the world scene" by the end of World War II. Id. at 123. Smuts played a substantial role in the post-war formation of the United Nations. See id. "In one of the supreme ironies of the twentieth century, Smuts was asked to draft the Preamble to the Untied Nations Charter." Id. Ironically, Smuts, who endorsed White superiority and racial segregation, drafted a document that called for the nations of the world "to guarantee fundamental human rights. individual dignity, and nondiscrimination between the sexes, none of which Smuts guaranteed in South Africa." Id.

8. See South Africa: History, supra note 2.

9. See id.

10. The doctrine of apartheid espoused the separation of every race and nation so that each would develop to the fullest along its own inherent lines. See South Africa Post-Colonial History: Recent History, supra note 3. Each racial group maintained its own territorial area within which to develop its unique cultural personality. See id. "Apartheid was separation by race and separation by location." LINDSAY MICHIE EADES, THE END OF APARTHEID IN SOUTH AFRICA 33 (1999). Scholars debate whether apartheid consisted merely of separation by another name, albeit involving more ruthless tactics. See NIGEL WORDEN, THE MAKING OF MODERN SOUTH AFRICA 105 (3d ed. 2000). See id. at 74-136 for a detailed analysis of the segregationist ideas and policies that led to the apartheid regime's formation and the tactics which defined the heyday of apartheid in South Africa from the 1950s to 1976. See also L.E. NEAME, THE HISTORY OF APARTHEID (1962) (discussing the general history dating to Dutch occupation of Table Bay in 1652); GWENDOLEN M. CARTER, THE POLTICS OF INEQUALITY: 
led to a series of interrelated laws and measures aimed at restructuring South African society. ${ }^{11}$

South Africa withdrew from the British Commonwealth in 1961 and became a republic. That same year, the African National Congress (ANC) ${ }^{12}$ formed a military wing under the leadership of Nelson Mandela. ${ }^{13}$ The group opposed the NP's repressive policies and attempted to force the government to negotiate by attacking white-owned property, while at the same time trying to avoid causing harm to people. ${ }^{14}$ The government detained Mandela in 1962 and sentenced him to life imprisonment in 1964 on charges of sabotage. ${ }^{15}$ Nevertheless, he remained a focal point for opposition to apartheid. ${ }^{16}$

Hendrik Verwoerd, who gained control of South Africa in $1958,{ }^{17}$ is generally known as apartheid's chief architect and leading ideologue. ${ }^{18} \mathrm{He}$ took the first steps toward a new version of apartheid that replaced explicit racism as a rationale for the denial of civil rights to blacks. The new version rationalized territorial segregation on the grounds that the Native Reserves

SOUTH AFRICA SINCE 1948 75-118 (1958) (discussing apartheid's effects on specific racial groups and detailing various acts that the government passed between the 1948 election and the mid-1950s); EADES, supra (discussing the historical background of apartheid, the crisis point reached in the 1980s due to the economic strains and conflicting nature of its ideology, and the system's eventual collapse in the 1990s); and WORDEN, supra, at 137-69 (discussing the decline and fall of apartheid).

11. The Malan government introduced the following laws and measures between 19481959 with the purpose of conforming South African society to the doctrine of apartheid: the Population Registration Act, which provided for the classification of the entire population on the basis of race; the Immorality Act, banning sexual relations between whites and blacks, was extended to include relations between whites and coloreds; inter-racial marriages were forbidden: the Group Areas Act served to intensify urban segregation by designating particular residential areas for specific races; race segregation in public places was introduced on a widespread basis and was given legislative sanction by the Separate Amenities Act, which stated that separate amenities need not be of equal standard; the Bantu Education Act removed black education from the care of the ministry of education to that of native affairs; the Extension of University Education Act removed the right of non-white students to attend certain previously available universities; and, in order to protect itself against radical opposition, the government introduced the Suppression of Communism Act, banned the South African Communist Party, and decreed that persons named as communists could be subjected to a wide range of restrictions. See South Africa Post-Colonial History: Recent History, supra note 3.

12. The ANC, formed in 1912, saw its members become active protesters of the NP's policies in the 1950s. Early tactics consisted primarily of mass civil disobedience. See id.

13. See generally ANTHONY SAMPSON, MANDELA (1999), for a comprehensive biography separated into distinct segments of the leader's life, from his birth in 1918 through 1999 . See also NELSON MANDELA, LONG WALK TO FREEDOM (1994) (autobiography); NELSONMANDELA, NELSON MANDELA SPEAKS: FORgING a DEMOCRATIC NonRaClal SOUTH AFRICA (Steve Clark ed., 1993) (various speeches given by Mandela between 1990-1993, the formative years leading toward constitutional reform).

14. See South Africa Post-Colonial History: Recent History, supra note 3.

15. See id.

16. See id.

17. Hard-liner J.G. Strydom replaced Daniel Malan in 1954. See id. Verwoerd succeeded to control four years later upon Strydom's death. See id.

18. See id. 
constituted the historic homelands of different African nations. ${ }^{19}$ The idea was to lead the homelands to individual self-government while maintaining the balance of power in the hands of government-appointed chiefs. ${ }^{20}$ The government's interest in reducing the settled population of Africans in white areas grew during this time and culminated in the launch of a massive campaign to force Africans into overcrowded homelands. ${ }^{21}$ Measures were more drastic than those taken during the early stages of apartheid and thus required more ruthless repression to enforce them. ${ }^{22}$

\section{B. Movement Toward Reform}

Change loomed on the horizon in 1978 when P.W. Botha succeeded as prime minister of South Africa. ${ }^{23}$ Under Botha, the government took steps toward reform, ${ }^{24}$ including approval in 1983 for the creation of a tricameral

19. See id. The 1913 Natives Land Act set up the "Native Reserves." See Z. Pallo Jordon. The National Question in Post 1994 South Africa, at http//:www.anc.org.za/ancdocs/ discussion/natquestion.html (last visited Feb. 9, 2001). The government set aside $13 \%$ of the nation's land area for Africans and effectively disallowed them from owning land in the remaining $87 \%$ of the country except by special license. Under Verwoerd, the government passed the Bantu Self-government Act in 1961, supposedly as the first step in granting independence to the developing "bantu nations." The "Native Reserves" were now redefined as "Bantu homelands" and any claims by Africans in the rest of the country were illegitimate and viewed as "intrinsically seditious." This was the beginning of the South African "Homeland" system. See id.

20. See id. The South African government granted "Independence" to Transkei (1976), Bophuthatswana (1977), Venda (1979), and Ciskei (1981), each of which utilized a parliamentary government (all remained dependent on South Africa for financial support). See South Africa: History, supra note 2. The remaining six homelands were territorial authorities, having much autonomy but remaining part of the republic. See id. The charade of "decolonization" (i.e. granting so-called "independence" to some homelands, or Bantustans, while at the same time continuing to forcibly remove "surplus" Africans to those Bantustans) fooled no one; indeed, foreign governments refused to recognize the "independent" Bantustans. See BECK, supra note 1, at 165-66.

21. See South Africa Post-Colonial History: Recent History, supra note 3. Between 1960 and 1970 the government forcibly resettled more than 1.5 million Africans. See id.

22. See id. Powers of the security police were greatly extended at this time. See id. In 1968, the state security services were centralized under the authority of the Bureau of State Security. Statistics demonstrating an increase in the number of people who died in police custody supported reports of widespread torture. See id.

23. See WORDEN, supra note 10 , at 138 .

24. The balance of security-related influence shifted from the police to the armed forces with the abolishment of the Bureau of State Security. See South Africa Post-Colonial History: Recent History, supra note 3. The state security council became the primary decision-making organ, which greatly reduced the roles of the NP and parliament. Racial job restrictions were abolished and trade union rights further extended. The government repealed laws prohibiting inter-racial marriages and extra-marital sexual relations, as well as restrictions on multiracial sports participation. A president's council made up of nominated Coloureds and Indians, along with white nominees, replaced the senate and proposed the establishment of a tricameral parliament comprising separate houses for each group (blacks were denied inclusion in the central parliament, though the need for some political representation for the black population 
legislature under a new constitution. ${ }^{25}$ Although the United Democratic Front (UDF) ${ }^{26}$ promoted rejection of the constitutional plan based on its failure to provide representation for the black majority, elections were held in 1984 for the Colored House of Representatives and the Indian House of Delegates. ${ }^{27}$ The electoral college chose Botha as the country's first executive president. ${ }^{28}$ In January 1989, Botha withdrew from his official duties due to illness. ${ }^{29}$ His successor, F.W. de Klerk, gave little indication of any radical intentions upon entering as the new president. ${ }^{30}$ However, in response to increasing international and internal pressures on the government, ${ }^{31}$ President de Klerk took dramatic steps in February 1990. He released Nelson Mandela; he lifted bans on 36 different political organizations, including the ANC and UDF; he announced that the government intended to begin negotiating with black leaders, with a view toward a new constitution based on universal franchise; and he stated that the government would establish an independent judiciary to guarantee equality of every citizen, regardless of race. ${ }^{32}$ The end of 1990 saw the virtual disappearance of the remnants of traditional social segregation. ${ }^{33}$ In early 1991, de Klerk announced to parliament that all remaining legislation enshrining apartheid was to be repealed, including the Group Areas Act and

in the towns was recognized). See id. But see EADES, supra note 10, at 48 (noting that, although Botha's regime introduced reforms and insisted that Africans would be included in politics at the national level, it soon became apparent that a real change was not forthcoming for the African population). Education, health, and welfare reforms were minor and, most importantly, the government continued to resettle African peoples. See id.

25. See South Africa: History, supra note 2. The new constitution, which took effect in 1984 , set up an executive system with separate legislatures for Whites, Coloureds, and Indians, but none for Blacks. See id.

26. Various groups opposed to apartheid, including many with church affiliations and with multiracial memberships, formed the UDF in 1983 to further their anti-apartheid message. See South Africa Post-Colonial History: Recent History, supra note 3. The UDF won strong support from both Coloured voters (only $18 \%$ of whom participated in the presidential election) and Indian voters (even lower participation). See id.

27. See id.

28. See id.

29. See id.

30. See id.

31. See EADES, supra note 10, at 77-99. Many intellectuals in South Africa, as well as a majority of the NP, were convinced by 1989 that apartheid was an unsustainable option in the country and that the government should adopt the ANC as a negotiating partner. See South Africa Post-Colonial History: Recent History, supra note 3. In the U.S. President Bush began initiating a more active approach towards democratic change in South Africa. Representatives of the ANC, the NP, various African states, and both the U.S. and the former U.S.S.R. attended informal meetings in the United Kingdom. In September 1989, the U.S. indicated that if moves were not made within six months to release Nelson Mandela, President Bush would assent to an extension of economic sanctions against South Africa. See id.

32. See id.

33. See id. The government repealed the Separate Amenities Act - an important symbol of apartheid - in October 1990. See id. Polls in 1990 indicated a high degree of pessimism among South African Whites over the future of the country. See EADES, supra note 10, at 96. 
the Population Registration Act. ${ }^{34}$ The so-called "legal revolution" was complete by the end of June $1991 .^{35}$ In March 1992, white voters approved a referendum to end apartheid, setting the stage for party conferences to prepare for an interim constitution ${ }^{36}$ and the first-ever multiracial general election in South Africa. ${ }^{37}$

The ANC won the 1994 election with a convincing defeat of the National Party. ${ }^{38}$ The new government of National Unity met on May 10, 1994, with Mandela as president and de Klerk as vice-president. ${ }^{39}$

\section{RESTRUCTURING SOUTH AFRICA}

\section{A. A New Constitution}

After nearly two years of negotiation, South Africa adopted a new majority-rule constitution on May 8, 1996. ${ }^{40}$ The new Constitution, as the "supreme law of the Republic," 41 advocates a broad acceptance of democracy. ${ }^{42}$ Indeed, visions of democracy and national unification were the

34. See supra note 11 (briefly describing the Acts). In all, over 100 pieces of discriminatory legislation were repealed. See South Africa: History, supra note 2.

35. See South Africa Post-Colonial History: Recent History, supra note 3. The NP responded favorably by altering its own constitution, opening membership to all races. The EC and U.S. abandoned most economic sanctions, and the International Olympic Committee agreed to readmit South Africa, whom they previously banned because of the country's repressive policies. See id.

36. Talks between the government and the ANC in 1990 resulted in a Convention for a Democratic South Africa (CODESA) to be held in late December 1991. See South Africa: History, supra note 2. A later conference, CODESA 2, resulted in a committee to write the interim constitution. See id. The new document was to include a "bill of rights, recognition of minority language, cultural and civil rights, the creation of nine new provinces to replace old political boundaries, acceptance of 11 official languages, and provision for the reabsorption of the homelands into South Africa." Id.

37. See id.

38. See id. Following the election, with its basis for popular support dwindling, the National Party began to lose prominent progressive members and became a mere shadow of its previously-dominant affiliation. See id.

39. See id. In recognition of their efforts to bring an end to the apartheid era, Mandela and de Klerk each received the 1993 Nobel prize for peace. See id.

40. See South Africa Index: Constitutional Background, at http://www.uni-wuerzburg. dellaw/sf_indx.html(last visited Sept. 16, 2000). The Republic of South Africa ratified the interim Constitution on December 22, 1993, and it went into effect in April 1994. See id. Although the main features of the interim document were expected to remain in the final Constiution, the goal was to utilize the interim Constitution for a five-year transitional period in which a unified national government would attempt to end all ties with the past apartheid regime. The Republic adopted the new Constitution on May 8, 1996, and it entered into force in amended version on February 7, 1997. See id.

41. S. AFR. CONST. preamble.

42. For a brief discussion of the Constitution's main provisions, see South Africa Constitution and Cabinet, at http://www.newafrica.com (last visited Sept. 21, 2000). 
driving forces behind its formation, as evidenced by its Preamble. ${ }^{43}$ The "new" South Africa vows not to base protection for peoples on ethnic or racial characteristics, but rather to defend "fundamental human rights" ensure that "every citizen is equally protected by law." longer tolerates a system of segregation, but strives to be "united in . . . diversity." ${ }^{46}$

Although racial prejudices were the primary catalyst for a movement toward reform, the new Constitution addresses a much broader spectrum of discriminatory concerns. The Founding Provisions state that " $[t]$ he Republic of South Africa is one sovereign democratic state founded on the following values: ... b) [n]on-racialism and non-sexism."177 The inclusive nature of the Provisions is further demonstrated by section three, regarding citizenship: "[a]ll citizens are . . . equally entitled to the rights, privileges and benefits of citizenship." 48

This broader spectrum of concerns can best be observed in the Bill of Rights, ${ }^{49}$ the "cornerstone of democracy in South Africa."so Based on the long-standing tradition of ethnic oppression in South Africa, the Bill of Rights is arguably the Constitution's most significant feature, barring discrimination directly or indirectly against anyone on the basis of "race, gender, sex, pregnancy, marital status, ethnic or social origin, colour [sic], sexual orientation, age, disability, religion, conscience, belief, culture, language ... . [or] birth.",51

With a view toward expansive protection of the aforementioned rights, the framers of the Constitution made the courts readily accessible to those wishing to redress a situation in which their fundamental rights are

\section{Preamble of the new Constitution:}

We, the people of South Africa, Recognise [sic] the injustices of our past; Honour [sic] those who suffered for justice and freedom in our land; Respect those who have worked to build and develop our country; and Believe that South Africa belongs to all who live in it, united in our diversity. We therefore, through our freely elected representatives, adopt this Constitution as the supreme law of the Republic so as to - Heal the divisions of the past and establish a society based on democratic values, social justice and fundamental human rights; Lay the foundations for a democratic and open society in which government is based on the will of the people and every citizen is equally protected by law; Improve the quality of life of all citizens and free the potential of each person; and Build a united and democratic South Africa able to take its rightful place as a sovereign state in the family of nations. May God protect our people .... .

\section{S. AFr. CONST, preamble.}
44. Id.
45. Id.
46. Id.
47. S. AFR. CONST. ch. $1, \S 1$.
48. Id. \& 3(2)(a).
49. See generally S. AFr. CONST. ch. 2.
50. Id. \&7(1).
51. Id. $\$ 9(3)$. 
threatened. ${ }^{52}$ When interpreting the Bill of Rights, a court must "promote the values that underlie an open and democratic society based on human dignity, equality and freedom." 53

The new Constitution provides for various state institutions whose primary mission is to support constitutional democracy. ${ }^{54}$ Examples include the Human Rights Commission; ${ }^{55}$ the Commission for the Promotion and Protection of the Rights of Cultural, Religious and Linguistic Communities;, and the Commission for Gender Equality. ${ }^{57}$ As a complement to the various state institutions vested with authority to investigate constitutional concerns, the new Constitution provides a specific, judicial enforcement mechanism in the Constitutional Court. ${ }^{58}$ The eleven-member Court ${ }^{59}$ is the highest court in South Africa with regard to all constitutional matters. ${ }^{60}$ It deals solely with constitutional matters and issues connected with decisions on those matters. ${ }^{61}$

\section{B. Conflicting Ideals}

Part of what remained in 1993 from centuries of ethnic separation, including the regime of apartheid and the homeland system, were the various rural units of indigenous peoples in South Africa. ${ }^{62}$ Indeed, this predominantly black segment of society constituted a majority of the South African popula-

52. Judicial standing is given to:

(a) [a]nyone acting in their own interest; (b) anyone acting on behalf of another person who cannot act in their own name; (c) anyone acting as a member of, or in the interest of, a group or class of persons; (d) anyone acting in the public Id. $\$ 38$.

interest; and (e) an association acting in the interest of its members.

Further, "[e]veryone has the right to have any dispute ... decided in a fair public hearing before a court ...." Id. $\$ 34$.

53. $I d . \S 39(1)(a)$.

54. See generally id. ch. 9.

55. See id. $\$ 184$. The objects of the Commission are to: “(a) promote respect for human rights and a culture of human rights; (b) promote the protection, development and attainment of human rights; and (c) monitor and assess the observance of human rights in the Republic." Id. § 184(1).

56. See id. $\$ \S 185-86$. Included in the primary objects of the Commission are: "(a) to promote respect for the rights of cultural, religious and linguistic communities; . . . and (c) to recommend the establishment of recognition, in accordance with national legislation, of a cultural or other council or councils for a community or communities in South Africa." Id. $\S$ $185(1)$.

57. See id. $\S 187$. "The Commission for Gender Equality must promote respect for gender equality and the protection, development and attainment of gender equality." Id. \& 187(1).

58. See generally id. ch. 8 .

59. "The Constitutional Court consists of a President, a Deputy President and nine other judges." Id. § 167 (1).

60. See id. \&167(3).

61. See id. The Constitutional Court has the inherent power to protect and regulate its own process, and to develop the common law "in the interests of justice." Id. $\$ 173$.

62. See BECK, supra note 1, at 188. 
tion. ${ }^{63}$ These groups continue to engage in traditional and often distinctive cultural practices, which they regulate through a system of "customary law." Although today's South African government espouses unification of the country's diverse peoples, it also recognizes the cultural benefits inherent in that diversity. ${ }^{65}$ The Constitution seeks to protect customary law and its practice by indigenous peoples. ${ }^{66}$ The Bill of Rights states that "[e]veryone has the right to use the language and to participate in the cultural life of their choice ...,",67 and that "[p]ersons belonging to a cultural ... community may not be denied the right ... to enjoy their culture . ..." For Further, chapter twelve of the Constitution expressly recognizes traditional leadership and the system of customary law. ${ }^{69}$

Although the Constitution offers protection for the rights of indigenous groups to practice cultural traditions and maintain a system of customary law, questions arise as to whether it does so on a merely facial basis. A limitations clause follows each grant of cultural freedom in the Bill of Rights and restricts that grant to situations that are consistent with the Bill of Rights as a whole. ${ }^{70}$ Section thirty-six of the Constitution specifically addresses the general limitation of rights and provides courts with a set of criteria to apply when balancing competing rights and interests. ${ }^{71}$ Since many customary law

63. The Transkei, Ciskei, Bophuthatswana, and Venda Bantustans together totaled over seven million citizens at the time. See id.

64. "In South African jurisprudence, there is no single interpretation of the concept Customary Law. It is however generally understood as the cumulative of all legislative enactments and judicial pronouncements on African social tradition and custom." Yvonne Mokgoro, The Customary Law Question in the South African Constitution, 41 ST. LouIs U. L.J. 1279,1281 (1997). Customary law is primarily unwritten and based largely on acceptance of standards of behavior. See 7 GEOFFREY V.DAVIS, SOUTH AFRICA 195 (Robert G. Neville et al., eds., 2 Rev. ed. 1994). For a general discussion of the concept of customary law see Mokgoro, supra, at 1281-83.

65. See, e.g., S. AFR. CONST. \& 6. Subpart (1) lists the eleven official languages of South Africa, after which subpart (2) states "[r]ecognising [sic] the historically diminished use and status of the indigenous languages of our people, the state must take practical and positive measures to elevate the status and advance the use of these languages." Id. $\$ 6(2)$.

66. There are two systems of law that are enforced in South Africa, Roman-Dutch common law and customary law.

67. S. AFR. CONST. \& 30.

68. Id. \&31(1)(a).

69. See id. ch. $12 \S 211$. Customary law is also expressly provided for in $\S 39$, which states in subpart (3) that " $[t]$ he Bill of Rights does not deny the existence of any other rights or freedoms that are recognised [sic] or conferred by ... customary law ...." Id. \& 39 .

70. See, e.g., id. $\$ \S 30-31$. Although the Constitution protects various cultural, religious and linguistic freedoms, the rights may not be exercised "in a manner inconsistent with any provision in the Bill of Rights." Id. This "subject to" idea is found in $\$ 39$ (recognizing customary law) and $\S 211$ (recognizing traditional leadership and customary law) as well. See id. $\S 39(3), 211(1)$.

71. See id. $\S 36$. The rights in the Bill of Rights can be limited in very few situations. Relevant factors include: "(a) the nature of the right; (b) the importance of the purpose of the limitation; (c) the nature and extent of the limitation; (d) the relation between the limitation and its purpose; and (e) less restrictive means to achieve the purpose." Id. $\$ 36(1)$. This clause 
practices result in discrimination, ${ }^{72}$ the question arises whether such practices can rationally be upheld under a constitution that specifically forbids such conduct. $^{73}$

Intestate succession ${ }^{74}$ procedures demonstrate the difficulties encountered by the South African government in attempting to recognize and maintain a system of customary law under the new Constitution and, specifically, a Bill of Rights that espouses equality among all South Africans.

\section{INTESTATE SUCCESSION}

\section{A. Customary Law - Official Version}

Customary laws were shaped by a pre-colonial society in which patriarchy and an extended family structure were distinctive features. ${ }^{75}$ Patriarchy implied that senior males exercised all significant rights and powers. ${ }^{76}$ "The extended family structure implied an extension of the nuclear unit through polygynous marriages and through connections with ascending and descending generations in the male line." $\mathrm{A}$ secure basis of support and protection resulted from this expansive network of kin. ${ }^{78}$

The key items of property in the subsistence-based pre-colonial economy were land and livestock. ${ }^{79}$ The head of the family had overall control of this property; however, his primary responsibility was providing for dependants. ${ }^{80}$ Thus, the entire family had an interest in the land and herds and, consequently, customary law recognized outright ownership in very few items of property. ${ }^{81}$

would presumably come into play in a court's consideration whether to apply customary law in a case in which such application would be inconsistent with the common law and the general principles of the Constitution (human dignity, equality, and freedom).

72. An example is the discrimination against women that is prevalent in the customary law of intestate succession, which is based on the male-dominated system of primogeniture.

73. See generally Mokgoro, supra note 64; Yvonne Mokgoro, The Protection of Cultural Identity in the Constitution and the Creation of National Unity in South Africa: A Contradiction in Terms?, 52 SMUL. REV. 1549 (1999) (discussing the apparent contradiction between cultural identity and national unity under the Constitution of the Republic of South Africa).

74. A person dying without a will is said to have died intestate. THE HON M M CORBETT ET AL., THE LAW OF SUCCESSION NN SOUTH AFRICA 581 (H R Hahlo ed., Juta \& Co, Ltd. 1980). Intestate succession laws determine distribution of a person's property after death. See generally id. at 581-90.

75. See South African Law Commission, Project 90, Discussion Paper 93, Customary Law $\S 1.2$ (2000) [hereinafter South African Law Commission, Discussion Paper 93].

76. See id.

77. Id.

78. See id.

79. See id. \$1.3.

80. See id.

81. See id. Recognition of complete ownership existed for only certain intimate items of property such as "wearing apparel, tools of trade and the livestock that for ritual reasons were deemed to belong to specific individuals." Id. 
From this socio-economic structure, certain important principles of succession developed within customary law. Individuals could not devise property by will; rather, property had to pass by intestacy. ${ }^{82}$ Nor was property divided into shares under the system. ${ }^{83}$ The inheriting individual effectively "stepped into the shoes" of the deceased, whose possessions, rights and duties all transferred to the heir. ${ }^{84}$ Further, heirs were determined by their relationship to the deceased through the male line only. ${ }^{85}$ To summarize, traditional customary law systems of succession in South Africa were "intestate, universal and patrilineal." ${ }^{\text {" } 6}$ With regard to the patrilineal nature of inheritance, the principle of male promigeniture guided customary succession. ${ }^{87}$ Finally, the deceased's family privately regulated the system of customary succession, without any interference from outside authorities in most cases. $^{88}$

Traditional custom law succession, alternatively termed the "official" version, ${ }^{89}$ revolved around the marital status of the deceased. ${ }^{90}$ Where the deceased was monogamous, the various systems of customary law in South Africa were uniform in applying the law. ${ }^{91}$ The deceased's oldest son was the first choice as heir. ${ }^{92}$ If that son had already died, then the oldest son's oldest son succeeded..$^{93}$ Failing any male issue in the oldest son's line, succession passed to the deceased's second son and his male descendants. ${ }^{94}$ This process continued through the line of all the deceased's sons, in order of seniority. ${ }^{95}$

If a deceased had no male descendants, his father was heir. ${ }^{96}$ If the father was dead, the deceased's oldest brother was heir, and if he was dead, the oldest brother's oldest son, or, alternatively, the oldest surviving male descendant

82. See id. $\$ 1.4$.

83. See id. \& 1.5 .

84. See Harmonisation of the Common Law and Indigenous Law (Draft Issue Paper on Succession), \& 2 (1998). This process represents a true example of succession, which means transmission of all the rights, duties, powers and privileges associated with a social status. See South African Law Commission, Discussion Paper 93, supra note 75, \$1.5. Although the terms "inheritance" and "succession" are often used interchangeably, inheritance really involves the transmission of property rights only. See id.

85. See South African Law Commission, Discussion Paper 93, supra note 75, \$1.6.

86. Harmonisation of the Common Law and Indigenous Law, supra note 84, § 2.

87. See id. "A deceased's heir is his oldest son, failing whom, the oldest son's oldest male descendant." Id.

88. See South African Law Commission, Discussion Paper 93 , supra note $75, \S 1.8$. This procedure is distinguishable from common law practice, under which the appointment of heirs and distribution of the estate are supervised by state officials. See id.

89. See generally id. $\$ 4.1$.

90. See id.

91. See id. $\S \S 4.1 .2-4.1 .4$.

92. See id. § 4.1.2.

93. See id.

94. See id.

95. See id.

96. See id. 
was next in line. ${ }^{97}$ Failing the deceased's oldest brother and his descendants, the next senior brother and his descendants were next to inherit. ${ }^{98}$ Failing any male issue in the first order of male ascendants, the deceased's grandfather succeeded, failing whom, the deceased's oldest paternal uncle or the uncle's oldest male descendant. ${ }^{99}$ Failing the paternal uncles, in order of seniority, and their descendants, the estate passed to the next order of male ascendants. ${ }^{100}$ The process continued until the oldest male relation in a particular line of ascendants became heir to the estate. ${ }^{101}$

Polygynous marriages necessitated a modification of the succession process, because by there nature these marriages resulted in the male's household being divided into separate "houses." 102 Each of a man's marriages established an independent house, the property of which was kept separate from his other houses because the heir to that house inherited the estate. ${ }^{103}$ The nature of the system of polygyny ${ }^{104}$ thereafter determined the order in which the house heirs succeeded. ${ }^{105}$ If there were no male descendants within a polygynous household, the order of succession followed the basic principles of a monogamous marriage. ${ }^{106}$

The "official" version of customary law prohibited a woman from succeeding to the status of a man because she did not have the legal power to perform typically male roles. ${ }^{107}$ Therefore, a woman neither succeeded to a role as head of a family nor did she inherit property from her deceased husband. However, provided that a widow was willing to remain at the homestead of her deceased husband, she was entitled to support out of the estate for the rest of her life. ${ }^{108}$

Marriages under customary law involved two families, not just the individual spouses. ${ }^{109}$ At the husband's death, both families attempted to ensure that the marital and family relationships continued with as little disruption as possible. ${ }^{110}$ In furtherance of this goal, the male heir would retain

97. See id.
98. See id.
99. See id
100. See id.
101. See id.
102. See id. $\S \S 4.1 .5-4.1 .9$.
103. See id.
104. The system of polygyny could be "simple" or "complex." For a discussion of each
10. See id. $\$ \S 4.1 .6-4.1 .8$.

105. See id.

106. See id. \$ 4.1.9. In the unlikely event that a deceased had no male relatives, in the "official" version of customary law a traditional leader took over the estate and was obligated to provide for the deceased's family from estate assets. See id. \$ 4.1.10. Modern practice would likely see the property escheat to the state. See id.

107. See id. \$ 4.1.11 (citing Myazi v. Nofenti, 1 NAC 74 (1904) and Kumalo v. Estate Kumalo, 1942 NAC (N\&T) 31.

108. See id.

109. See id. $\$ 4.10 .2 .1$.

110. See id. 
and protect the widow with the help of the deceased's family. If the deceased left no male heir, or the widow was still capable of bearing children, she was expected to enter a levirate union "11 with one of her deceased's husband's younger brothers. ${ }^{112}$ The widow's support from her husband's estate, therefore, did not come without attached strings.

Finally, the traditional customary law system of intestate succession considered the deceased's male heir the owner of the estate, thus possessing him with the right to dispose of the estate as he saw fit. ${ }^{113}$ His rights and powers were subject only to the support duties he had toward the surviving widow and children and tempered by his obligation to consult the widow before disposing of major assets. ${ }^{14}$

\section{B. Customary Law - Living Version}

The outline of customary law offered above owes more to the nineteenth century than it does to the present day. ${ }^{115}$ "It is now generally acknowledged that the 'official version' of customary law, although frequently consulted as the most readily available source, is often inaccurate and misleading."116 Socio-economic conditions have slowly but steadily changed in southern African states, ${ }^{117}$ resulting in a modern version of customary law, often termed the "living" version. 18

An independent study, Women and Law in Southern Africa Research Trust (WLSA), ${ }^{119}$ reported changes in the system of customary succession. ${ }^{120}$ It found that the lower courts of traditional rulers today stand prepared to

111. By entering a levirate union with her deceased husband's brother, for whom she was expected to perform the normal duties of a wife, the woman retained support obligations from the husband's family. See id. \$4.10.2.2. Although Colonial govemments in South Africa made no attempts to prohibit the institution of levirate unions, they did require that the widow enter such a union voluntarily. Nevertheless, her freedom to choose was in practice narrowly circumscribed due to the probable loss of support if she refused. See id.

112. See id.

113. See id. \$ 4.1.12.

114. See id.

115. See id. \& 4.2.1.

116. Id. § 4.2.2.

117. With monogamy as the norm today, the extended family structure constitutes a system in decay. See id. This has led to a weakening of the support obligations owed to women and children. Further, women have gained a higher status, resulting in wives often acting as breadwinners in the family and playing traditionally "male" roles. See id.

118. See generally id. \$ 4.2.

119. Research into South African customary law practices is sparse. See id. $\$ 4.2 .3$. However, an independent group, Women and Law in Southern Africa Research Trust (WLSA), has conducted an extensive investigation with regard to succession practices in Botswana, Lesotho, Mozambique, Swaziland, Zambia, and Zimbabwe. South Africa was excluded from this study; however, based on the numerous shared legal and social institutions among the southern African states, the WLSA findings are a recommended tool for studying succession in South Africa. See id.

120. See generally id. $\$ \S 4.2 .4-4.2 .16$. 
disregard the strict rules of customary law in order to respond more readily to perceived social needs as, for example, where strict application would work an injustice on a widow. ${ }^{121}$ Second, the WLSA study found that rules of succession have changed somewhat. ${ }^{122}$ The overall goal has become less of a desire to uphold the patriarchal order and more to respond to the needs of the deceased's survivors. ${ }^{123}$ In this regard, although the oldest son might still take the largest share of the estate, other of the deceased's children inherit individual portions as well. ${ }^{124}$ Also in this regard, it appears that widows have stronger estate claims today than they had under the "official" version of customary law. ${ }^{125}$ Such is often the case when the deceased has left young children to raise. ${ }^{126}$ This "tendency to allow a deceased's children and surviving spouse to become the main beneficiaries of the estate realistically accepts basic social needs." 127

Notwithstanding the increased attention and deference that have been given to the position of widows and children in the modern system of custom law succession, traditional rules have by no means disappeared. ${ }^{128}$ In fact, "[b]y persisting alongside new and emergent rules, they give individuals an opportunity to manipulate the dual system to their own advantage - and the very flexibility and ambiguity of customary law can work against the welfare of deserving beneficiaries." 129 For instance, one method used by selfinterested heirs is to deny that the woman making a claim against the estate was actually married to the deceased. ${ }^{130}$ Considering that the formation of a customary marriage is a potentially lengthy and ambiguous process, ${ }^{131}$ denying the existence of a marriage is not as difficult as it might seem. ${ }^{132}$ Further, where an informal union existed between the woman and the deceased, male heirs have better claims to the estate. ${ }^{133}$ Finally, it is important to note that

121. See id. \$ 4.2.4. Interestingly, higher courts (those further removed from the indigenous peoples), although aware of the two applicable "versions" of customary law, tend to refer strictly to the "official" version. In effect, application in this way directly contravenes the original purpose of customary law - "to create an environment conducive to the care and protection of the deceased's family ...." Id.

122. See id. \& 4.2.5.

123. See id.

124. See id. § 4.2.6. However, female children remain excluded when the estate contains a minimal amount of property. See id.

125. See id. \$ 4.2.8.

126. See id.

127. Id. $\$ 4.2 .8$. Succession in Botswana occurs not as a single event, but as a timely process. See id. $\S 4.2$.10. When a man dies, his estate effectively passes to his widow, who exercises control until her own death. At that time, the oldest son inherits his portion of the estate. See id.

128. See id. § 4.2.13.

129. Id. $\S 4.2 .13$.

130. See id. \$ 4.2.14.

131. See infra note 269.

132. See South African Law Commission, Discussion Paper 93, supra note 75, at $\$ 4.2 .14$.

133. See id. This holds true no matter how long the union existed between the woman and the deceased. See id. 
widows are rarely in a position to enforce their rights. ${ }^{134}$ Maintaining family peace and harmony is important, and women often waive any rights they might have in order to preserve these attributes - that is, if the deceased's family has not already simply overlooked the woman's rights, which is not unlikely. ${ }^{135}$

\section{Common Law}

For South Africans who follow Roman-Dutch common law, dying intestate leads to application of the Intestate Succession Act. ${ }^{136}$ The Act is similar to those found in many jurisdictions in the United States. ${ }^{137}$ Distribution of intestate property follows a mechanical approach based on a hierarchy of blood relations. ${ }^{138}$ For instance, if the deceased is survived by a spouse, but no descendants, then the spouse inherits the entire estate. ${ }^{139}$ If the deceased is survived by both a spouse and descendants, they divide the property among them. ${ }^{140}$ Provisions are then made for situations in which the deceased is survived only by parents ${ }^{141}$ or by siblings, ${ }^{142}$ and finally for the possibility that no one from any of the aforementioned groups survives the deceased. ${ }^{143}$ In that case, "the other blood relation or blood relations of the deceased who are related to him nearest in degree shall inherit the intestate estate in equal shares."144

The Intestate Succession Act therefore provides a straight-forward approach to property distribution upon death of the intestate. ${ }^{145}$ Unlike

134. See id. \$ 4.2.16.

135. See id.

136. See generally Intestate Succession Act 81 of 1987.

137. See, e.g., IND.CODE ANN. \$29-1-2-1 (West 2000) (distribution of net intestate estates in Indiana).

138. See generally Act 81 , supra note $136, \S 1(1)$. Spouses are given primary importance in the distribution scheme. See id. $\$ 1(1)(a) ; \S 1(1)(c)$. The remainder of the interested parties (other than adoptive children) constitute the blood relations of the decedent.

139. See id. $\$ 1(1)(a)$. In the opposite situation, in which the decedent is survived by a descendant and no spouse, the descendant inherits the entire estate. See id. $\$ 1$ (1)(b).

140. See id. \$1(1)(c).

141. See id. $\$ 1(1)(d)$

142. See id. \& 1(1)(e). Siblings include so-called "half-bloods" as well as whole-blood relations. See id. \&1(2).

143. See id. $\$ 1(1)(\mathrm{f})$.

144. Id. The Act makes no provision for property distribution if the deceased dies leaving no ascertainable blood relative. See generally Act 81 , supra note 136 . Presumably, the estate would escheat to the state in this situation, which occurs in similar systems of intestate estate distribution. See, e.g., IND. CODE ANN. \& 29-1-2-1(d)(8) (West 2000).

145. Scholars and professionals continue to debate the merits of a mechanical system of succession as opposed to support-based or behavior-based systems, which give succession-right considerations to those individuals who either offered continuous support to or were dependent upon support from the deceased during his lifetime. See generally Frances H. Foster, Towards a Behavior-Based Model of Inheritance?: The Chinese Experiment, 32 U.C. DAVIS L. REV. 77 (1998): Frances H. Foster, Linking Support and Inheritance: A New Model From China, 1999 WIS. L. REV. 1199 (1999). Further, behavior-based schemes imply an ability to keep a "bad" heir from inheriting. See Paula A. Monopoli, "Deadbeat Dads": Should Support and Inheritance be Linked?, 49 U. MIAMI L. REV. 257, 259-60 (1994) (discussing application in the 
customary law procedures, the Act does not foster discrimination against women or children. ${ }^{146}$ In fact, the deceased's widow and children are the primary beneficiaries under the Act, ${ }^{147}$ thereby meeting the needs and expectations of modern society.

The Intestate Succession Act obviously meets the Bill of Rights' equality and non-discrimination requirements. Customary law practices, at least with regard to intestate succession, fall short of those same requirements. Therein lies the dilemma faced by the South African Government. The Government claims to celebrate diversity amongst its many indigenous groups, and seemingly protects their customary practices in the new Constitution. ${ }^{148}$ At the same time, however, the government scrutinizes those practices to determine whether or not they are consistent with the "westernized"149 version of the Bill of Rights. Where customary laws diverge from the Bill of Rights, changes are sought in order to bring such laws in line with the new Constitution.

\section{LAW REFORM}

\section{A. South African Law Commission}

The South African Law Commission (SALC) ${ }^{150}$ conducts a majority of the research connected with the government's attempts at bringing customary law in line with the Constitution. The Commission is an advisory body whose aim is the continuous renewal and improvement of the law of South Africa. ${ }^{151}$ "Professional independence, careful and comprehensive research and open

United States of mechanical systems to deadbeat dads and suggesting that behavior-based models should be considered).

146. See Act 81, supra note 136.

147. See id.

148. See supra note 69 and accompanying text.

149. Traditional leaders use this term to describe what they consider the undesirable path that the South African Government is taking with regard to customary law. See Khadija Magardie, South Africa: Customary Law Shake-up, AfrICA NEws, Aug. 18, 2000. They do not see a need to run their country with "Western" techniques and policies. See id.

150. The Commission was established by the South African Law Commission Act 19 of 1973.

151. See Objects and Constitution of the South African Law Commission, at http://www. law.wits. ac.za/salc/objects.html (last modified Mar. 10, 1997). The objects of the commission are:

to do research with reference to all branches of the law of the Republic and to study and to investigate all such branches of the law in order to make recommendations for the development, improvement, modernization or reform thereof, including - the repeal of obsolete or unnecessary provisions; the removal of anomalies; the bringing about of uniformity in the law in force in the various parts of the Republic; and the consolidation or codification of any branch of the law. 
procedures ..."152 are characteristic features of the reform process. ${ }^{153}$ Within the context of "open procedures," the Commission strives to achieve maximum involvement of the community at large, which it does by following an orderly, step-by-step procedure when acting in the name of law reform. ${ }^{154}$

The process begins with the submission to the Commission of a law reform proposal. ${ }^{155}$ Although proposals typically emanate from the Minister of Justice, members of the government, parliamentarians and state departments, proposals may also come from the general public. ${ }^{156}$ The Commission itself might also initiate law reform proposals. ${ }^{157}$

After receiving a proposal submission, the working committee ${ }^{158}$ considers it for inclusion as a project, or investigation in the Commission's program. ${ }^{159}$ Each investigation is given a priority rating so that the most urgent matters are considered and researched first. ${ }^{100}$

The next step, after inclusion of an investigation in the Commission's program, is for the Commission to determine whether to establish a project committee in respect of the investigation. ${ }^{161}$ If the Commission deems a committee necessary, it chooses research candidates based on their representation of the population and their knowledge in the particular field under investigation. ${ }^{162}$

The fourth step, publication of an issue paper, is essential to the reform process because it serves as the beginning of the community's participation in that process. ${ }^{163}$ The purpose of publishing an issue paper is "to announce a particular investigation ...., to elucidate the problems that have given rise to the investigation, to point to possible options available for solving those problems and to initiate and stimulate debate on identified issues."164 Issue papers, which precede the publication of any other document in the law reform

152. Functioning and Policies of the [South African Law] Commission, at http://www.law. wits.ac.za/salc/ function.html (Feb. 9, 2001).

153. See id.

154. See generally id.

155. See id. §1.

156. See id. "[A]ny person or body is at liberty to approach the Commission with a request to investigate a particular branch or aspect of the law which in his or her opinion is in need of reform." Id.

157. See id.

158. The working committee serves as the executive committee of the Commission. See generally id.

159. See id. \& 2.

160. See id.

161. See id. \& 3. Factors considered when making this determination include the "complexity or specialised [sic] nature of the subject matter of the investigation and the availability of external expertise." Id.

162. See id. However, the Commission tries to balance a potential member's knowledge and experience in the field with the danger that partisan participation in the project committee itself will result. See id.

163. See id. \$ 4.

164. Id. The SALC borrowed this process from the Australian Law Commission, who has had encouraging results from the use of issue papers in the past. See id. 
process, ensure direct involvement of the community at the beginning of an investigation and help to broaden the consultative base. ${ }^{165}$ After approving it for publication, the Commission distributes the paper among interested persons, bodies and institutions in hopes of eliciting feedback, usually in written form, on the issues raised. ${ }^{166}$

After considering both the comment received on an issue paper and the project committee's interim research, the researcher in charge of the investigation prepares a draft discussion paper. ${ }^{167}$ Included in the paper are the following: "[a] definition of the problems requiring solutions; the existing state of the law in relation to the problems; a comparative legal study; possible preliminary solutions to rectify the problems identified; [and] a summary of the preliminary proposals ...."168 The procedure toward publication ${ }^{169}$ mirrors that for issue papers, and the paper is then distributed to interested parties for comment on the proposals. ${ }^{170}$

After the comments on a discussion paper are received and studied, a draft report is prepared. ${ }^{171}$ The report contains the Commission's final recommendations and, where applicable, draft legislation to give effect to the recommendations. ${ }^{172}$ It is submitted to the Minister of Justice and typically published in the Government Gazette in its final form. ${ }^{173}$

Because of the lengthy, orderly, and democratic process that the SALC goes through with regard to law reform, the South African Government gives strong deference to their legislative recommendations. Areas in which the Commission has had an impact, with a resulting effect on the customary lawBill of Rights question, include marriage law and succession law.

\section{B. Marriage law}

As discussed in section III above, customary law application of intestate succession rules traditionally depended on the marital status of the

165. See id.

166. See id.

167. See id. \& 5 .

168. Id. If considered appropriate, a proposed draft Bill in which the proposals are embodied might also warrant inclusion in the draft discussion paper. See id.

169. A notice in the Govermment Gazette and media statements publicize the discussion paper. See id. This procedure is used to give all interested parties - including both governmental and non-governmental organizations, as well as the general public - the chance to participate in and contribute to the law reform process. "[I]t also ensures that its [the Commission's] final recommendations are the product of debate, discussion and community involvement." Id.

170. See id. "It is made clear that the opinions expressed in discussion papers do not represent the Commission's final views and that such documents are merely a further step in the consultation process." Id.

171. See id. 87.

172. See id.

173. See id. $\$ 8$. 
parties. ${ }^{174}$ However, marital inquiries are not limited solely to whether the relationship was monogamous or polygynous. An equally important consideration is the system in which the individuals married.

The Black Administration Act ${ }^{175}$ defined the various types of marriages into which an African person could enter. He or she could enter into a marriage in community of property, resulting in co-ownership of the joint estate in equal and undivided shares. At death, it is irrelevant who brought what into the marriage - the estate is simply halved and each party is able to bequeath his or her own half-share as he or she sees fit. Indigenous blacks can enter into such a system, provided that within one month prior to the marriage the couple declares to a magistrate that it is their intention and desire that community of property shall result from the marriage. ${ }^{176}$

Africans could also marry out of community of property by ante-nuptial contract according to the law of the land. This system provides that a husband and wife each have separate estates throughout the marriage. ${ }^{17}$ At death, each can bequeath his or her own property as he or she chooses. ${ }^{178}$

Finally, if the indigenous couple chooses neither of the above systems of marriage, they will likely form a union according to traditional customary law and the relationship will be recognized in accordance with the customs and norms pertaining to indigenous African law.

The choice by an indigenous African to marry according to customary law traditionally resulted in dramatic and inconsistent effects on intestate succession procedures followed at the death of a spouse. The South African High Court addressed those issues in the Zondi case, in which an illegitimate child of a deceased widower sought a declaratory order stating that regulations that resulted in the deceased's brother inheriting the estate were unconstitutional. ${ }^{179}$

174. See South African Law Commission, Discussion Paper 93, supra note 75, § 4.1.

175. See Black Administration Act 38 of 1927.

176. See Zondi v. President of the RSA and Others, 1999 (11) BCLR 1313 (N).

177. Today, there are two types of marriage with regard to ante-nuptial contracts. The traditional form, in which the couple takes an ante-nuptial contract without accrual, results in each party maintaining their own assets and liabilities throughout the marriage, with no financial adjustments to either's estate when the marriage is dissolved. A more modern approach is the ante-nuptial contract with accrual system. Again, each party maintains his or her own estate during the marriage; however, the couple will share equally in the growth of the estate upon dissolution of the marriage. This approach serves to protect the lesser-earning spouse, who may have expended more labor and resources while the other spouse purchased more property in his or her own name. See Peter Eggeling, Ante Nuptial Contract Advisory Services, in MATRIMONY, April 26, 2000.

178. A difference between this system and a marriage in community of property is the way in which property is divided at death. Under ante-nuptial contract, each individual bequeaths their own property. Under a marriage in community of property, however, each item of property must be effectively halved and the individuals can only bequeath their half of the item, thus creating difficulty when property is bequeathed to third parties. See id.

179. See Zondi v. President of the RSA and Others, 1999 (11) BCLR 1313 (N). 
In Zondi, the estate of the deceased was administered in terms of Regulation R200, which forms part of the Regulations for the Administration and Distribution of the Estates of Deceased Blacks. Section $2^{180}$ of the Regulations sets forth how the intestate property of a "Black" shall be distributed. The Zondi court determined that the deceased had not been part of a marriage in community of property or under ante-nuptial contract, ${ }^{181}$ and the regulation therefore mandated a distribution "according to Black law and custom." 182 Under customary law illegitimate children do not inherit, and the deceased's brother was deemed heir to the estate. ${ }^{183}$ The deceased's illegitimate child sought a declaration invalidating the regulations on grounds of being inconsistent with the new Constitution. ${ }^{184}$

The judge noted at the outset that the deceased, whose wife died almost three years earlier, had not been married in community of property when the two were married in 1953. ${ }^{185}$ The judge discussed this in terms of the Black Administration Act and the fact that the couple had not declared before a magistrate their intention to marry in community of property. ${ }^{186} \mathrm{Next}$, the judge discussed the issue of intestate succession and the fact that the regulations draw a distinction between an out of community property marriage

180. Section 2 of the Regulations provides:

If a Black dies leaving no valid will, so much of his property, including immovable property, as does not fall within the purview of subsection (1) or subsection (2) of section 23 of the [Black Administration] Act shall be distributed in the manner following: ... (c) [i]f the deceased, at the time of his death was - (i) a partner in a marriage in community of property or under antenuptial contract; or (ii) a widower, widow or divorcee, as the case may be, of a marriage in community of property or under ante-nuptial contract and was not survived by a partner to a customary union entered into subsequent to the dissolution of such marriage, the property shall devolve as if the deceased had been a European. (d) When any deceased Black is survived by any partner - (i) with whom he had contracted a marriage which ... had not produced the legal consequences of a marriage in community of property; or (ii) with whom he had entered into a customary union; or (iii) who was at the time of his death living with him as his putative spouse; or by any issue of himself and any such partner, and the circumstances are such as in the opinion of the Minister to render the application of Black law and custom to the devolution of the whole, or some part, of his property inequitable or inappropriate, the Minister may direct that the said property or the said part thereof, as the case may be, shall devolve as if the said Black and the said partner had been lawfully married out of community of property, whether or not such was in fact the case, and as if the said Black had been a European. (e) If the deceased does not fall into any of the classes described in paragraphs (a), (b), (c), and (d), the property shall be distributed Id. according to Black law and custom.

181. Had he been married in one of these two ways, the Regulations provide that his estate pass as if he were a "European." Thus, the Intestate Succession Act of 1987 would apply.

182. Id. \& 2(e).

183. See Zondi v. President of the RSA and Others, 1999 (11) BCLR 1313 (N).

184. See id.

185. See id.

186. See id. 
and marriages entered into by ante-nuptial contract or in community of property. ${ }^{187}$ In the latter situations, the Intestate Succession Act of 1987 governs the distribution. ${ }^{188}$ The Act, in turn, provides that "illegitimacy shall not affect the capacity of one blood relation to inherit the intestate estate of another blood relation."189 Therefore, the deceased's child would have inherited the estate. In this situation, where the marriage was out of community of property, illegitimacy did matter and, in fact, kept the deceased's child from inheriting.

The judge's concern stemmed from the fact that the deceased was not simply married according to customary law practices. He and his spouse intentionally contracted a marriage out of community of property, which the judge viewed as pointing away from customary law. ${ }^{190}$ The decisive question became whether the regulations, which differentiated between various types of marriages, were constitutional under the new Bill of Rights. ${ }^{191}$

Ultimately, the judge held that the regulation in question offended the equality provisions of the Constitution. ${ }^{192}$ He pointed to the "gross discrimination" that is present when illegitimate children inherit from deceased African persons who married by ante-nuptial contract or in community of property, whereas those same children do not inherit if a marriage was contracted out of community of property. ${ }^{193}$ The Court ordered that the deceased's property pass according to the Intestate Succession Act of $1987 .{ }^{194}$

Although case law concerning the conflict between customary marriage systems with their effect on intestate succession and the equality provisions of the new Constitution is somewhat limited at the current time, one need only look to the SALC to find the roots of legislative proposals and statutory changes that affect the rights of indigenous Africans under customary law.

The Commission's research into South African marriage practices culminated in Parliament's 1998 passage of the Recognition of Customary

187. See id.

188. See id.

189. Intestate Succession Act 81, supra note $136, \S 1(2)$.

190. See Zondi v. President of the RSA and Others, 1999 (11) BCLR 1313 (N).

191. See id.

192. See id.

193. See id.

194. See id. Judge Levinsohn held:

[t]o the extent that ... the Regulations for the Administration and Distribution of the Estates of Deceased Blacks ... distinguishes for the purpose of intestate succession between the estates of Black persons who . . . had been ... a partner in a marriage which ... was not a marriage in community of property on the one hand, and the estates of Black persons who ... had . . . been a partner in a marriage under ante-nuptial contract or a marriage in community of property on the other hand it is inconsistent with the Constitution of the Republic of South Africa and is accordingly invalid.

Id. But see Mthembu v. Letsela and Another, 1998 (2) SA 675 (T), in which Judge Mpati questioned the correctness of Judge Levinsohn's decision. 
Marriages Act ("the Act"). ${ }^{195}$ The primary aim of the Act is to extend full legal recognition to marriages entered into in accordance with indigenous or traditional rites. ${ }^{196}$ This recognition, in turn, serves the goal of improving the position of women and children within customary marriages by introducing measures that bring customary law in line with the Constitution. ${ }^{197}$

Prior to commencement of the Act, South African law failed to recognize any marriage other than a "Western Christian marriage."198 The Act defines the term "customary marriage" as "a marriage concluded in accordance with customary law."199 "Customary law," in turn, means "the customs and usages traditionally observed among the indigenous African peoples of South Africa and which form part of the culture of those peoples." ${ }^{200}$ Section 2 of the Act provides for the recognition of all customary law marriages, including polygamous marriages. The recognition is retroactive ${ }^{201}$ in nature, thus effectively including every valid customary law union within its coverage. ${ }^{202}$

One of the primary objectives of the SALC in proposing new legislation and of Parliament in passing the Act was to set up a registration system in South Africa for marriages and divorces. ${ }^{203}$ Traditionally, indigenous peoples have not considered registration of their marriages to be a high priority. ${ }^{204}$ This has led to an inability of the national government to keep track of important statistical information that is necessary if it is to provide any type of support programs to its rural citizens. ${ }^{205}$ Section 4 of the Act therefore provides for a registration system for customary marriages. ${ }^{206}$

195. See Recognition of Customary Marriages Act 120 of 1998, REPUBLC OF SOUTH AFRICA GOVERNMENT GAZETTE, Dec. 2, 1998, at 2 [hereinafter Act 120 of 1998].

196. See generally id.

197. See id. \$\$ 6-7. The statute's text summarizes Parliament's goals in passing the Act:

[t]o make provision for the recognition of customary marriages; to specify the requirements for a valid customary marriage; to regulate the registration of customary marriages; to provide for the equal status and capacity of spouses in customary marriages; to regulate the proprietary consequences of customary marriages and the capacity of spouses of such marriages; to regulate the dissolution of customary marriages; ....

Id. preamble.

198. Professor T. Nhlapo, The Customary Marriages Act: Background and Rationale, in Towards Improving the Registration of Marriages and Divorces in South Africa, Part One, at http://www.statssa.gov.za/Publications/Marrigaes\%20and\%20dovorce\%20proceedings/full \%20text.htm (last visited Nov. 7, 2000). The SALC's efforts in its latest research was based on its 1985 report entitled Marriages and Customary Unions of Black Persons, for which an investigation was conducted under the Harmonisation [sic] of Indigenous Law and Common Law project. See id.

199. Act 120 of 1998 , supra note 195,81 (iii).

200. Id. \& 1(ii).

201. See id. $\$ \S 2(1), 2(3)$.

202. See id. $\$ 3$ for the validity requirements of customary marriages.

203. See Nhlapo, supra note 198.

204. See id.

205. See id.

206. See Act 120 of 1998, supra note 195, § 4. However, the Act does little to truly mandate compliance with the registration requirements. Although the Act states that indigenous 
Section 6 of the Act offers wives of customary unions equal status with their husbands. ${ }^{207}$ At first view it would seem that, notwithstanding the grant of "full status and capacity," 203 discriminatory customary practices will nevertheless be upheld. The equality granted is "subject to the matrimonial property system governing the marriage." 209 In other words, if a customary marriage is out of community of property Section 6 really does little to improve the situation of wives; indeed, a wife's right to equal treatment would not take priority over the customary norm of disallowing her to inherit property. However, Section 7 takes care of this issue by stating that customary marriages entered into after commencement of the Act will be in community of property and of profit and loss "unless such consequences are specifically excluded by the spouses in an ante nuptial contract which regulates the matrimonial property of their marriage."210 The equality provisions of Section 6 are thus given much greater effect because, although a wife's equality is subject to the matrimonial property system governing the marriage, that governing system will now in most cases be a system in community of property. ${ }^{211}$

The Department of Justice, in administering the Act, touted the worthy attempts of the Act to give expression to two constitutional principles, namely "the right to systems of family law based on any tradition or religion and the right to cultural pluralism."212 It seems, however, that the Act provides little more than lip service to the right to cultural pluralism, at least with regard to property issues. Although the Act allows indigenous peoples to marry under whatever system of law they choose, it effectively deprives them of important cultural practices in the event that they choose customary law. The marriage might be "customary" in name, but in many respects it will be regulated by the common law.

\section{Succession Law}

Along with changes related to marriage systems, South Africa will also begin to see direct effects on the practices of indigenous peoples through various modifications in the laws of succession and related areas affecting succession.

couples have certain time frames within which they "must" register their customary marriages, the final clause in section 4 effectively releases them from that duty, stating: "[f]ailure to register a customary marriage does not affect the validity of that marriage." Id. $\S 4(9)$.

207. See id. §6.

208. Id.

209. Id.

210. Id. \& $7(2)$.

211. See id. This effective invalidation of customary marriage property systems is not retroactive - "[t]he proprietary consequences of a customary marriage entered into before the commencement of this Act continue to be govemed by customary law." Id. $\$ 7(1)$.

212. Department of Justice: Legislation Index, at http://www.doj.gov.za/legislation/indexacts.html (last visited Nov. 7, 2000). 
The SALC published a draft issue paper on succession in May $1998 .^{213}$ In September of that year the Amendment of Customary Law of Succession Bill $^{214}$ was introduced to Parliament with the purpose "[t]o extend the South African law of testate and intestate succession to all persons ...."215 The Bill proffered amendments to the Intestate Succession Act of 1987 and the repeal of Section 23 of the Black Administration Act of 1927 to "ensure protection of the interests of spouses and children of polygamous marriages."216 The Council of Traditional Leaders ${ }^{217}$ objected to the Bill, accused the SALC of lack of consultation in the process, and warned against attempts at "Westernizing" the customary law of succession. ${ }^{218}$ The Bill was quashed in its infancy. ${ }^{219}$

At the same time Parliament was addressing the first draft bill dealing with succession, South African courts were also considering customary succession issues in the Mthembu case. ${ }^{220}$ The controversy revolved around the legitimacy of a customary union between the plaintiff and the intestate deceased, and whether the plaintiff and the child of her and the deceased should inherit from the estate rather than the deceased's father. ${ }^{221}$

Tebalo Watson Letsela (the deceased) died in August 1993. At his death he was the holder of a ninety-nine year leasehold title in some property on which he lived with the plaintiff and her two daughters, one of whom, Tembi Mthembu, was his child. The deceased had no other issue, but was survived by his father (the defendant), mother, and three sisters. His parents shared a house on the property with the plaintiff and her daughters. At Letsela's death, the property passed to his father by virtue of the customary law rule of

213. See South African Law Commission, Project 90, Issue Paper 12, Harmonisation [sic] of the Common Law and Indigenous Law: Draft Issue Paper on Succession in Customary Law (1998).

214. See Amendment of Customary Law of Succession Bill 109 of 1998, at http://www. gov.za/bills/1998/b109-98.pdf (last visited Nov. 2, 2000).

215. Id. preamble.

216. Id. \& 6.

217. The Council was established by the Council of Traditional Leaders Act 10 of 1997 with the objectives: "(a) to promote the role of traditional leadership within a democratic constitutional dispensation; (b) to enhance unity and understanding among traditional communities; and (c) to enhance co-operation between the Council and the various Houses [of traditional leaders] with a view to addressing matters of common interest." Id. $\$ 7(1)$. Section $7(2)$ sets forth the Council's advisory role - the Council may advise the national government, investigate and make recommendations relating to any of the following: "(i) [m]atters relating to traditional leadership; (ii) the role of traditional leaders; (iii) customary law; and (iv) the customs and communities observing a system of customary law." Id. $\S 7(2)$. The Council's name was changed to the National House of Traditional Leaders in 1998. See Council of Traditional Leaders Amendment Act 85 of 1998.

218. See Magardie, supra note 149.

219. See id.

220. See Mthembu v. Letsela and Another, 1998 (2) SA 675 (T).

221. See Mthembu v. Letsela and Another, 2000 (3) SA 867 (SCA). 
succession. ${ }^{22}$ The plaintiff sought an order declaring that the customary rule of primogeniture and Regulation 2 of the Regulations for the Administration and Distribution of the Estates of Deceased Blacks were invalid based on their inconsistencies with the Constitution.

The case reached the Supreme Court of Appeal of South Africa in May $2000 .^{223}$ The plaintiff-appellant argued that the customary rule of succession, specifically the principle of primogeniture, was grossly discriminatory toward all Black women and that it contravened the equality provisions in Section 8 of the interim Constitution ${ }^{224}$ because it discriminated on the grounds of sex and gender. The Court refused to decide the case based on gender, although it did refer to discussion from the first $M$ thembu ruling ${ }^{225}$ in which the judge stated that the deceased's customary male heir would have an obligation to support the appellant and the deceased's daughter, thereby keeping the procedure in line with the Constitution's equality principles. ${ }^{226}$

The Supreme Court instead addressed the legitimacy of the daughter. ${ }^{227}$ Although the deceased paid the first installment of lobola, ${ }^{228}$ the appellant and the deceased never entered into a customary union; therefore, the appellant's child was an illegitimate child of the deceased. ${ }^{229}$ The Court upheld the applicability of Regulation 2 and held that the deceased's property was appropriately distributed according to Black law and custom. ${ }^{230}$ Because the daughter was illegitimate, and not because she was female, ${ }^{231}$ the deceased's father was the proper heir to the estate.

222. See id. The magistrate ordered the property to devolve according to Black law and custom in accordance with the Black Administration Act 38 of 1927. The magistrate was also a defendant in the case. See id.

223. See Mthembu v. Letsela and Another, 2000 (3) SA 867 (SCA).

224. The equality provisions are found in Section 9 of the new Constitution of the Republic of South Africa, Act 108 of 1996.

225. Mthembu v. Letsela and Another, 1997 (2) SA 936 (T).

226. See Mthembu v. Letsela and Another, 2000 (3) SA 867 (SCA). (citing Judge Le Roux's opinion from the 1997 judgment).

227. See id.

228. "Lobola" refers to the property in cash or in kind which a prospective husband or the head of his family undertakes to give to the head of the perspective wife's family in consideration of a customary marriage. It is often referred to as "bridewealth," and demonstrates the importance of family in the customary union of two individuals. Critics of the practice, however, have cited it as the primary example of male domination and exploitation in pre-Colonial South African socities. See Shawn Riva Donaldson, "Our Wornen Keep Our Skies from Falling": Women's Networks and Survival Imperatives in Tshunyan, South Africa, in African FEMINISM: THE POLTICS of Survival IN SUb-Sartaran AFrica 257, 262 (Gwendolyn Mikell ed., 1997).

229. See Mthembu v. Letsela and Another, 2000 (3) SA 867 (SCA). The Court also discussed the customary law of succession and explained that the legitimacy of the appellant's daughter would really be irrelevant - "whether or not Tembi is the deceased's legitimate child, being female, she does not qualify as heir to the deceased's estate. Women generally do not inherit in customary law." Id.

230. See id.

231. The Court commented that the holding would have been the same had the illegitimate child been male. See id. 
In upholding the customary law practice of denying a widow and her daughter the right to inherit from a late husband, Mthembu highlighted the conflict between the Constitution and indigenous cultures. ${ }^{232}$

The Mthembu ruling was interesting considering its timing. The decision came on the heels of Parliament's passage in February 2000 of the Promotion of Equality and Prevention of Unfair Discrimination Act. ${ }^{233}$ The Act reaffirms the goals of the Constitution; its purpose, in essence, is to promote equality and prohibit and eliminate unfair discrimination. ${ }^{234}$ The preamble of the Act indicates its applicability to customary law practices that conflict with the Constitution's equality provisions. ${ }^{235}$ Further, the Act refers to "discrimination" as "any act or omission, including a . . . practice . . . which directly or indirectly ... withholds benefits, opportunities or advantages from any person on one or more of the prohibited grounds."236 "Prohibited grounds" include "race, gender, sex, pregnancy, marital status, ethnic or social origin, colour [sic], sexual orientation, age, disability, religion, conscience, belief, culture, language and birth." 237

The Act states that, in its application, the following should be recognized and taken into account: "(a) [t]he existence of systematic discrimination and inequalities, particularly in respect of . . gender . . . as a result of past and present unfair discrimination, brought about by colonialism, the apartheid system and patriarchy; and (b) the need to take measure at all levels to eliminate such discrimination and inequalities." 238 The Act is binding on the State and all individuals. ${ }^{239}$ It should prevail in the event that conflicts arise

232. See South African Law Commission, Discussion Paper 93, supra note 75, $\S \S 1.4 .2$ $-1.4 .6$.

233. See Promotion of Equality and Prevention of Unfair Discrimination Act 4 of 2000 , REPUBUCOF SOUTH AFRICA GOVERNMENT GAZETTE, Feb. 9, 2000. It appears from the Court's decision that it was unwilling to step out of the Constitutional scope of review at the time of Mthembu, at least with regard to questions of conflict between customary law and the Constitution. The new Act was not mentioned or considered by the Court in its decision.

234. See id. The complete scope of the Act is "to prevent and prohibit unfair discrimination and harassment; to promote equality and eliminate unfair discrimination; to prevent and prohibit hate speech; and to provide for matters connected therewith." Id.

235. See id. preamble. The Act seeks the "eradication of social and economic inequalities, especially those that are systematic in nature, which were generated in [South Africa's] history by colonialism, apartheid, and patriarchy...." (emphasis added). ld. It notes that "systematic inequalities and unfair discrimination remain deeply embedded in social structures, practices and attitudes" and that "[t]he basis for progressively redressing these conditions lies in the Constitution which, amongst others, upholds the values of human dignity, equality, freedom and social justice in a united, non-racial and non-sexist society where all may flourish." (emphasis added). Id.

236. Id. ch. 1 \& 1 (viii).

237. Id. ch. $1 \S 1$ (xxii). Prohibited grounds also include "any other ground where discrimination based on that other ground: (i) causes or perpetuates systematic disadvantage; (ii) undermines human dignity; or (iii) adversely affects the equal enjoyment of a person's rights and freedoms in a serious manner ...." Id.

238. Id. ch. 1 \& $4(2)$.

239. See id. ch. $1 \S 5$. 
between its provisions and those of any other law, "other than the Constitution or an Act of Parliament expressly amending [the] Act."240

Section 8 of the Act deals with the prohibition of unfair discrimination on the basis of gender. ${ }^{241}$ It states:

[n]o person may unfairly discriminate against any person on the ground of gender, including -. . . . (c) the system of preventing women from inheriting family property; (d) any practice, including traditional, customary or religious practice, which impairs the dignity of women and undermines equality between women and men ... ; [and] (e) any policy or conduct that unfairly limits access of women to land rights, finance, and other resources .... ${ }^{242}$

In order to determine the fairness or unfaimess of a given practice or policy, equality courts ${ }^{243}$ will consider the grounds on which the alleged discrimination took place. ${ }^{244}$ If the discrimination took place on a ground listed in the definition of "prohibited grounds" it is unfair "unless the respondent proves that the discrimination is fair."245 In determining whether the respondent has proved that the discrimination is fair the court considers various factors, including the impact of the discrimination on the complainant, the nature and extent of the discrimination, whether there is a legitimate purpose for the discrimination and whether the discrimination is narrowly tailored to achieve its purpose. 246

The question arises whether the Mthembu decision was correct in light of the Equality Act's passage. Although the Court expressed that it was deciding the case based on illegitimacy and not on gender, the discrimination

240. Id.

241. See generally id. ch. $2 \S 8$.

242. Id.

243. See generally id. ch. 4.

244. See id. \& 21.

245. Id.ch. 3 \& 13(2)(a).

246. See id. ch. $4 \S 14$. The complete list of factors that equality courts consider are:

[ $w$ ] hether the discrimination impairs or is likely to impair human dignity; (b) the impact or likely impact of the discrimination on the complainant; (c) the position of the complainant in society and whether he or she suffers from patterns of disadvantage or belongs to a group that suffers from such patterns of disadvantage; (d) the nature and extent of the discrimination; (e) whether the discrimination is systematic in nature; (f) whether the discrimination has a legitimate purpose; (g) whether and to what extent the discrimination achieves its purpose; (h) whether there are less restrictive and less disadvantageous means to achieve the purpose; (i) whether and to what extent the respondent has taken such steps as being reasonable in the circumstances to - (i) address the disadvantage which arises from or is related to one or more of the prohibited Id. grounds; or (ii) accommodate diversity. 
at issue was nonetheless prohibited by the Act on grounds of birth. ${ }^{247}$ Doubt arises as to whether the next Mtembu-type case will come out in favor of protecting customary law.

Within a few months after the Mthembu decision the SALC published its discussion paper on succession in customary law. ${ }^{248}$ The paper is a continuation of the project that ended with the withdrawal from Parliament of the 1998 succession law amendment proposals, and it includes a new Draft Bill for the Amendment of the Customary Law of Succession ("Draft Bill"). ${ }^{249}$

The Discussion Paper makes the following important proposals: to reform the order of succession so as to provide a material basis of support for the deceased's surviving spouse and children; to amend the Intestate Succession Act to cover the estates of deceased persons who were subject to customary law; to ensure the inheritance of surviving spouses and children; to remove the disqualification of out-of-wedlock children from inheriting; and, to secure the right of the surviving spouse to the matrimonial home and its contents, especially with regard to small estates. ${ }^{250}$

As with the 1998 Draft Bill, the main objectives of the current Draft Bill are to apply the Intestate Succession Act 81 of 1987 to all South Africans dying intestate, ${ }^{251}$ to repeal section 23 of the Black Administration Act ${ }^{252}$ that regulates succession in respect of black persons, and to enact new provisions which will be consistent with the Constitution.

"The Intestate Succession Act provides a convenient solution for most of the problems in customary law."253 It complies with the Bill of Rights and secures the material welfare of surviving spouses and children. The Draft Bill proposes the repeal of Section 1(4)(b) of the Intestate Succession Act, which excludes from coverage estates subject to customary law. ${ }^{254}$ Thereafter, Section 1(1), which sets forth the different inheritance scenarios, will determine the order of succession in all cases of total or partial intestacy. ${ }^{255}$ In other words, failing a testamentary disposition of property by the deceased, all estates will devolve according to the Intestate Succession Act. ${ }^{256}$

247. See id. ch. 1 \& 1 (xxii).

248. See South African Law Commission, Discussion Paper 93, supra note 75.

249. See id. annexure.

250. See South African Law Commission, Summary of Discussion Paper 93 on Customary Law, at http://www. law.wits.ac.za/salc/discussn/paper93sum.html (last visited Oct. 4, 2000).

251. See Draft Bill for the Amendment of the Customary Law of Succession $\$ 2(1)(2000)$.

252. See id. § 5(b).

253. South African Law Commission, Discussion Paper 93, supra note 75, § 4.6.1.

254. See id. \& 2(2)(cc). Section 1(4)(b) of the Intestate Succession Act states that, for purposes of determining who shall inherit the intestate estate of a deceased individual, "'intestate estate' includes any part of any estate ... in respect of which section 23 of the Black Administration Act, 1927 (Act 38 of 1927), does not apply." Act 81, supra note 136, § 1(4)(b).

255. See Act 81 , supra note $136, \S 1(1)$.

256. Retroactive application to customary marriages is found in section 2(2) of the Draft Bill: "[t]he Intestate Succession Act ... applies with the changes required by the context to the intestate estate of a person who before the coming into operation of this Act entered a valid 
Making the Intestate Succession Act generally applicable will cure other inconsistencies between indigenous practices and the Bill of Rights. Section 1(2) will address the illegitimacy dispute that was prevalent in Mthembu. ${ }^{257}$ "By providing that illegitimacy does not affect the capacity of one blood relation to inherit the intestate estate of another blood relation, this section will bring customary law into line with the constitutional principle of nondiscrimination on the ground of birth."258

Section 1(4)(e)(i) of the Intestate Succession Act states that an adopted child shall be deemed a descendant of his adoptive parents. ${ }^{259}$ This section will supersede any customary law to the contrary and will provide uniform consequences for the adoption of both males and females. ${ }^{260}$

The SALC proposes the maintenance of certain provisions of Section 1(1) of the Intestate Succession Act and the general applicability thereof. Section 1(1)(d) would thus mandate that the intestate estate pass to the parents of a deceased who is survived by neither a spouse nor descendants. ${ }^{261}$ If only one parent survives the deceased, the estate would be split between the surviving parent and the deceased's siblings. ${ }^{262}$ Section 1(1)(e) would address the situation in which the deceased is survived only by brothers and sisters. In this case, one half of the estate would be distributed to those siblings that are related to the deceased through the mother and one half would be distributed to those that are related through the father. ${ }^{263}$ This provision guarantees greater equality for half-bloods who, while possibly receiving less of an estate share, ${ }^{264}$ will not be ignored from the inheritance process. Finally, in the event that the deceased is not survived by a spouse, descendant, parent, or descendant of a parent, subsection ( $f$ ) would effectively pass the estate to the "blood relations of the deceased who are related to him nearest in degree. ..."265

customary marriage which subsisted at the time of that person's death." Draft Bill for the Amendment of the Customary Law of Succession \$ 2(2).

257. See Mthembu v. Letsela and Another, 2000 (3) SA 867 (SCA).

258. South African Law Commission, Discussion Paper 93, supra note 75, § 4.6.4.

259. See Act 81 , supra note $136, \S 1(4)(e)(i)$.

260. Indigenous groups following customary law have occasionally used adoption in order to perpetuate a bloodline. See South African Law Commission, Discussion Paper 93, supra note 75, § 4.6.5. An heirless head of a family would place a kinsman's male offspring in his house so that there would be a suitable heir for the estate. Although females might be taken into a house as well, succession rights would not result. General application of the Intestare Succession Act would prescribe equal treatment for adopted males and females, allowing both to succeed to a deceased parent's estate. See id.

261. See Act 81 , supra note $136, \$ 1(1)(d)(i)$.

262. See id. $\& 1$ (1)(d)(ii). Under this provision, the parent is entitled to one-half of the estate and the deceased's siblings are entitled to the other half, shared equally. See id.

263. See id. $\$ 1(1)(e)(\mathrm{i})$.

264. Half-blood siblings would receive less of a share if the deceased is survived by both full-blood and half-blood siblings. See id. $\S 1(1)(e)(i)(c c)$.

265. Id. \&1(1)(f). 
While the SALC recommends general application of most provisions of the Intestate Succession Act, it nonetheless realizes that certain amendments to the Act are required in order to meet the needs of those who are currently subject to customary law. ${ }^{266}$ The first amendment proposal concerns the definition of a surviving spouse. ${ }^{267}$ Currently, in order to inherit under the Act spousal claimants must establish a valid marriage. ${ }^{268}$ This requirement would effectively exclude many customary marriage partners whose marital status often remains ambiguous for an extended period of time. ${ }^{269}$ The SALC recommends redefining the term "surviving spouse" to include partners of informal unions. ${ }^{270}$

The second amendment proposal concerns polygynous marriages, which are now recognized as valid by the Recognition of Customary Marriages Act. ${ }^{271}$ The SALC's Draft Bill treats all wives equally, stating that if a deceased is survived "by more than one spouse, but not by a descendant, such spouses shall inherit the intestate estate in equal shares." 272

Finally, the third amendment proposal would require guaranteeing surviving partners certain assets in the estate. ${ }^{273}$ The Recognition of Customary Marriages Act makes customary marriages in community of property. ${ }^{274}$ Under the Intestate Succession Act a surviving spouse of a marriage in community of property automatically takes half of the marital estate. However, small estates might then be split into fractions, leaving insufficient support for a spouse. ${ }^{275}$ Research by the WLSA indicates that "small estates should be kept intact to ensure an efficient transmission of assets to the most deserving beneficiaries." ${ }^{276}$ Children will inherit, but they must wait until the

266. See South African Law Commission, Discussion Paper 93, supra note 75 \& 4.9.1.1.

267. See id. \$4.9.1.2.

268. See id.

269. See id. Customary marriages are not determined by a single event, but rather by a series of events such as the payment of lobola and various family gatherings. In this respect, it might be difficult to say precisely when a couple was actually "married." Therefore, an extension of the Act to cover only "valid" customary marriages would not go far enough. See id.

270. See id. \$ 4.9.1.4. The Recognition of Customary Marriages Act has improved the situation somewhat by providing that even unregistered marriages are deemed valid and also by its retroactive application to customary marriages. See Recognition of Customary Marriages Act 120 of $1998 \S 4(2) ; \S 4(9)$. Notwithstanding these improvements, however, the "probability exists that many partners may not qualify as 'spouses' under the Intestate Succession Act." South African Law Commission, Discussion Paper 93, supra note 75, § 4.9.1.4.

271. See Act 120 of 1998, supra note 195, §§ 2(3)-(4).

272. Draft Bill for the Amendment of the Customary Law of Succession \& 3(a)(ii). The Intestate Succession Act currently addresses only single-spouse marriages. See Act 81 , supra note $136, \S 1(1)$.

273. See South African Law Commission, Discussion Paper 93, supra note 75, §4.9.3.1.

274. See Recognition of Customary Marriages Act 120 of $1998 \& 7$.

275. See South African Law Commission, Discussion Paper 93, supra note 75, § 4.9.3.2 - 4.9.3.3.

276. Id. \& 4.9.3.3. 
surviving spouse dies. ${ }^{27}$ The result is "a smoother transition of wealth from one generation to the next."278 The SALC therefore recommends that small estates be exempted from division amongst beneficiaries, and that the surviving spouse be guaranteed rights to the deceased's house and household goods in their entirety. ${ }^{279}$

The SALC, in preparing the Draft Bill, also addressed an issue that was paramount in the Mthembu case. In the 1997 judgment (Mthembu I), the judge found that the customary rule of male primogeniture was indeed discriminatory, but that it was not unfairly discriminatory because of the concomitant obligations of the heir towards the widow and the rest of the deceased's dependents. ${ }^{280}$ Thus, he held that the system was not unconstitu-tional. ${ }^{281}$ The Supreme Court of Appeal later declined an invitation by applicant's counsel that it should "develop" the customary law rule to bring it in line with the equality provisions of the Constitution. ${ }^{282}$ The Court held that "[a]ny development of the rule would be better left to the legislature after a process of full investigation and consultation, such as is currently being undertaken by the Law Commission."283

In response to the Mthembu court's "suggestion" the SALC developed the law by substituting equality requirements in place of the heir's support duties. The Draft Bill, by amending the Intestate Succession Act so as to create a system of complete equality and by making the Act generally applicable, negates the necessity of an heir's duty to support the deceased's dependants. The Draft Bill therefore states that "[a]ny customary laws obliging an heir to maintain the dependants of a deceased person or to settle debts by the deceased are repealed."284

Recent developments in South African succession law paralleled the changes that have taken place with regard to marriage law. When considering the proposed treatment of illegitimate and adopted children, as well as halfblood siblings, the equal status granted to all wives within a polygynous marriage, the negation of support duties owed by an heir, and, most importantly, the general applicability of the new system to all South African marriages, it appears that mere lip service is being spent on the interest in

277. See id.

278. Id.

279. See id. \$ 4.9.3.4. This procedure is actually more in line with the living version of customary law in most areas, where the surviving spouse is left in control of the house and its contents, regardless of what statutory divisions require. See id. $\$ 4.9 .3 .3$. Section $2(3)$ of the SALC's Amendment Act states that "a spouse inherits the deceased's house and personal belongings."

280. See Mthembu v. Letsela and Another, 2000 (3) SA 867 (SCA) (citing Mthembu I).

281. See id.

282. See id. (citing Mthembu II).

283. Id.

284. Draft Bill for the Amendment of the Customary Law of Succession, Amendment to the Intestate succession Act 81 of $1987 \& 3(\mathrm{c})$. 
maintaining and respecting a system of customary law within the African legal heritage. In reality, if Parliament approves the SALC's proposals, few customary law remnants will remain with regard to intestate succession procedures in South Africa.

\section{CONCLUSION}

The new Constitution of the Republic of South Africa makes it clear that legislation must continue to respect the African legal heritage and the cultural practices of indigenous peoples. However, an express caveat exists which mandates that those practices take a subordinate position to the principles of equality and non-discrimination set forth in the Constitution. This contradiction between the desire to protect cultural identity and the need to be faithful to a modem, democratic Bill of Rights was recently tested in the area of intestate succession. The result seems to be a victory for the Constitution and a virtual refusal to accept customary law procedures as valid. The Promotion of Equality and Prevention of Unfair Discrimination Act, the Recognition of Customary Marriages Act, and the Draft Bill for the Amendment of the Customary Law of Succession have all served to create a situation in which indigenous peoples will now be regulated by a "Westernized" system of intestate succession.

The Honorable Yvonne Mokgoro, Justice of the Constitutional Court of South Africa, delivered a paper at the Saint Louis University School of Law in 1997. She concluded the discussion with her optimistic view that, "if customary law can survive the harmonization process, then all skepticism about its continued existence in a human rights legal order should become unnecessary."285 The following year, Mokgoro again considered the South African conflict between cultural identity and national unity in a paper she delivered at the Southern Methodist University School of Law. ${ }^{286}$ Her conclusion this time conceded that "the Bill of Rights exerts a superceding effect on cultural norms, practises [sic], and institutions, severing those features of a culture that are in conflict with the Constitution from the body of the culture and engrafting in their place the values which the Constitution upholds." 287 She then suggested that cultural values that coincide with the Constitution's basic premises will act as a "reinforcement of the required national consensus," and that, "[i]n view of this, the argument that cultural rights are an empty shell - a token offered in the cut and thrust of constitutional negotiations to obtain political consensus from interest groups - may be weakened."288 Two and a half more years have now passed and it seems that

285. Mokgoro, supra note 64, at 1289.

286. See Mokgoro, The Protection of Cultural Identity in the Constitution and the Creation of National Unity in South Africa: A Contradiction in Terms?, supra note 73.

287. Id. at 1560 .

288. Id. at 1560-61. 
the arguments can no longer be weakened. Intestate Succession is one example of proof that cultural rights are indeed an empty shell. Regardless of the light under which South Africans view the reforms, for better or for worse, it is apparent that indigenous cultures are once again being told to discard what they know and to accept what others wish to thrust upon them. This they have done since 1652.

Andrew P. Kult"

* J.D. Candidate, 2001, Indiana University School of Law - Indianapolis; B.S., 1995, Indiana University - Bloomington. I thank my wife, Kylie, not only for her patience throughout the drafting of this Note, but for her continual support and encouragement of my every endeavor. I also thank the editorial staff of the Indiana International \& Comparative Law Review for their efforts in helping me complete this Note. 
